\title{
A novel therapy for ovarian cancer using real-time imaging
}

\author{
ZHEN ZHANG, ZHAOJIE CHEN, BEIBEI XIE and HAIYAN ZHANG \\ Department of Gynaecology, Linyi People's Hospital, Linyi, Shandong 276003, P.R. China
}

Received September 17, 2015; Accepted September 27, 2016

DOI: $10.3892 / \mathrm{mmr} .2016 .6000$

\begin{abstract}
The present study was designed to develop an activable, dual-targeted theranostic platform combining fluorescent and cytotoxic templates to provide a novel strategy for specific drug delivery and cellular imaging in ovarian cancer cells. Two compounds of a folic acid-prodrug-doxorubicin (Dox) scaffold were synthesized, and their antiproliferative activities were evaluated using 3-(4,5-dimethylthiazol-2-yl)-2,5-diphenyltetrazolium bromide and flow cytometric analysis. The process of drug release was investigated using fluorescence emission spectra assay and confocal laser scanning microscopy. The results showed that the synthesized compounds exhibited potent antitumor activities against ovarian cell lines. Among them, compound 1e exhibited the most potent activity demonstrating half maximal inhibitory concentration values of $0.85 \pm 0.10,8.64 \pm 0.37$ and $0.81 \pm 0.03 \mu \mathrm{M}$ against $\mathrm{A} 2780$ A2780/Dox and A2780/cisplatin cell lines. The fluorescence imaging of live cell lines also provided an easy and reliable method to monitor site-specific drug activities through turn-on systems induced by drug release. The results of the present study may assist in the treatment of ovarian cancer cells with strengthened efficiency and real-time imaging, which may be used as a multifunctional system for the optimization of anticancer drugs.
\end{abstract}

\section{Introduction}

Cancer is a class of diseases, in which a group of cells exhibit uncontrolled growth, invasion and sometimes metastasis (1). Ovarian cancer remains the most frequent type of cancer among women, which is a heterogeneous cancer encompassing multiple subgroups with a complicated molecular basis $(2,3)$. Improvements in current understanding of the underlying biology of ovarian cancer may lead to novel therapeutic strategies. Several models of ovarian carcinogenesis have been suggested. One of the models involves the malfunction of tumor suppressors and the occurrence of oncogenes, thereby leading

Correspondence to: Dr Zhaojie Chen, Department of Gynaecology, Linyi People's Hospital, 27 East Section of Jiefang Road, Linyi, Shandong 276003, P.R. China

E-mail: zhaojiechen22@sina.com

Key words: folic acid, doxorubicin, prodrug, ovarian cancer to the hyperproliferation of epithelial cells and/or inactivation of DNA repair genes. Another model suggests the activation or deactivation of chromatin proteins associated with DNA, with resultant effects on different cellular processes $(4,5)$. In reference to these models, the field of DNA-targeted drug development has gained increased attention due to their high sensitivity and specificity.

Furthermore, due to the complicated molecular basis of ovarian cancer, certain clinical results have evaluated and encouraged the utility of combination therapies, including the combination of doxorubicin (Dox) and cisplatin (Cis), which are beneficial in the treatment of cancer (6-8). An optimized therapeutic strategy requires a drug delivery system, which can guide the drug into the targeted cancer cells and improve therapy. It is known that the overexpression of high-affinity folate receptors (FRs) on human cancer cells provides advantages in treating tumor cells without interfering with neighboring normal tissue $(9,10)$. For this reason, the FR is used as an attractive target for cancer treatment, further enforcing the selective active targeting in anticancer therapy $(11,12)$. In addition, a combination therapy is not complete without the real-time monitoring of the drug activity. Therefore, developing a sensitive and accurate platform to evaluate drug activities is critical in scientific investigations and clinical applications.

Inspired by the multifunctional chemotherapy, the present study was performed to design a combination therapy integrating a targeted delivery platform and an activatable real-time sensor. In the design, folic acid (FA) acted as a selective tumor-targeting ligand and a quencher for Dox fluorescence (13-16). A reducible platinum (Pt) (IV) prodrug and its palladium $(\mathrm{Pd})$ analogue were introduced as an activatable ligand with two axial positions linked to FA and Dox. Once this platform enters the tumor cells through FA targeting, the prodrug can be activated via reduction by several extracellular or intracellular reducing agents, including glutathione (GSH), cysteine and ascorbic acid, to achieve effective antitumor treatment $(17,18)$, with concomitant breakage of two axial bonds and the release of free Dox. This system showed a turn-on effect on fluorescence, thereby realizing the sensitive and site-specific detection of drugs. This design was based on a combination therapy, which can achieve optimal effectiveness due to their synergic roles in the ovarian cancer environment.

The combining of fluorescence imaging, a targeted delivery platform and combination chemotherapy provides advantages to treat ovarian cancer cells with improved efficiency and 
real-time imaging. Supported by the data of the present study, such conjugation provides improved efficiency and bioactivity, which can be used as a multifunctional system for the optimization of ovarian cancer treatment.

\section{Materials and methods}

Chemistry. All chemicals and reagents used in the present study were of analytical grade. All electrospray ionisation mass spectrometry (ESI-MS) spectra were recorded on a Mariner System 5304 mass spectrometer [Mariner Systems (UK) Ltd., Wokingham, UK]. Column chromatography was performed using silica gel (200-300 mesh) eluted with ethyl acetate and petroleum ether. Analytical reverse-phase high performance liquid chromatography (HPLC) analysis was performed on a Shimadzu HPLC system (Shimadzu Corporation, Kyoto, Japan) using the Grace ${ }^{\mathrm{TM}}$ Alltech $^{\mathrm{TM}}$ Alltima $^{\mathrm{TM}}$ C-18 (250x10 mm) column (Thermo Fisher Scientific, Inc., Waltham, MA, USA) at a flow rate of $3.0 \mathrm{ml} /$ min for preparation, and a C-18 $(250 \times 4.6 \mathrm{~mm})$ column at $1.0 \mathrm{ml} / \mathrm{min}$ for analysis. The ${ }^{195} \mathrm{Pt}$ NMR spectra were recorded on a Bruker AVANCE-400 spectrometer (Bruker Systems, Inc., Billerica, MA, USA). Elemental analyses were performed on a CHN-O-Rapid instrument (Heraeus, Hanau, Germany).

General procedure for FA-prodrug-Dox derivatives $(1 e-2 e)$. (1) Synthesis of $\mathrm{M}\left(\mathrm{NH}_{3}\right)_{2} \mathrm{Cl}_{2}\left(\mathrm{O}_{2} \mathrm{CCH}_{2} \mathrm{CH}_{2} \mathrm{CO}_{2} \mathrm{H}\right)$ [ $\mathrm{O}_{2} \mathrm{CCH}_{2}-\mathrm{CH}_{2} \mathrm{CONH}$-polyethylene glycol (PEG)-FA], Cis- $\left[\mathrm{MCl}_{2}\left(\mathrm{NH}_{3}\right)_{2}\right]$ (1 mmol; QianKun Chemistry Technology Co., Ltd., Shanghai, China) was suspended in water $(5 \mathrm{ml})$ and a 10-fold excess of $\mathrm{H}_{2} \mathrm{O}_{2}$ was added. The mixture was stirred for $4 \mathrm{~h}$ at $50^{\circ} \mathrm{C}$. Recrystallization of Cis- $\left[\mathrm{MCl}_{2}(\mathrm{OH})_{2}\left(\mathrm{NH}_{3}\right)_{2}\right]$ was performed in situ and collected. The mixture was washed with cold water, ethanol and ether, and dried in a desiccator. Subsequently, succinic anhydride $(4 \mathrm{mmol})$ was added to a suspension of Cis- $\left[\mathrm{MCl}_{2}(\mathrm{OH})_{2}\left(\mathrm{NH}_{3}\right)_{2}\right]$ in dimethylformamide (DMF; 5 ml; QianKun Chemistry Technology Co., Ltd.), and the reaction mixture was stirred at $70^{\circ} \mathrm{C}$ for $4 \mathrm{~h}$. The resulting solution was dried in vacuo, leaving a dark yellow oil, which was dissolved in a small volume of acetone $(5 \mathrm{ml})$. The addition of ether precipitated a solid, which was collected and dried in vacuo to leave the product as a powder. To a solution of Cis- $\left[\mathrm{MCl}_{2}\left(\mathrm{NH}_{3}\right)_{2}\left(\mathrm{O}_{2} \mathrm{CCH}_{2} \mathrm{CH}_{2} \mathrm{CO}_{2} \mathrm{H}\right)_{2}\right.$ in DMF $(10 \mathrm{ml})$, DMF solution $(0.5 \mathrm{ml})$ containing HATU $(1.5 \mathrm{mmol})$ was added,. This mixture was stirred for $10 \mathrm{~min}$ at room temperature. To the resulting solution, DMF solution containing PEG linker $(0.8 \mathrm{mmol})$ and $\mathrm{N}, \mathrm{N}$-diisopropylethylamine (DIPEA; 1.2 mmol; QianKun Chemistry Technology Co., Ltd.) was added. The mixture was stirred at room temperature for $24 \mathrm{~h}$ in the dark. The DMF was then removed under a vacuum and the resulting compound was purified using HPLC. FA (0.8 mmol; QianKun Chemistry Technology Co., Ltd.) was dissolved in $5 \mathrm{ml}$ DMF coupled with $0.5 \mathrm{mmol}$ of dicyclohexylcarbodiimide (DCC) and $1 \mathrm{mmol}$ of $\mathrm{N}$-hydroxysuccinimide (NHS). The reaction was stirred for $14 \mathrm{~h}$ at room temperature in the dark to obtain the folate-NHS ester. The resulting folate-NHS was reacted with $\left.\mathrm{M}\left(\mathrm{NH}_{3}\right)_{2} \mathrm{Cl}_{2} \mathrm{O}_{2} \mathrm{CCH}_{2} \mathrm{CH}_{2} \mathrm{CO}_{2} \mathrm{H}\right)$ $\left(\mathrm{O}_{2} \mathrm{CCH}_{2}-\mathrm{CH}_{2} \mathrm{CONH}-\mathrm{PEG}\right)$ in DMF and purified by reprecipitation. (2) Synthesis of $\mathrm{M}\left(\mathrm{NH}_{3}\right)_{2} \mathrm{Cl}_{2}\left(\mathrm{O}_{2} \mathrm{CCH}_{2} \mathrm{CH}_{2} \mathrm{CONH}-\mathrm{Dox}\right)$ $\left(\mathrm{O}_{2} \mathrm{CCH}_{2}-\mathrm{CH}_{2} \mathrm{CONH}-\mathrm{PEG}-\mathrm{FA}\right)$ : The synthesis of the final
Dox-prodrug-FA conjugates was performed using standard amide coupling reactions. Following the procedure mentioned above, 1.0 equiv prodrug-PEG-FA was reacted with 1.5 equiv 1-ethyl-3-(3-dimethylaminopropyl) carbodiimide (EDC; QianKun Chemistry Technology Co., Ltd.) coupled with DIPEA $(20 \mu \mathrm{l})$ in $2 \mathrm{ml} \mathrm{DMF}$ at a temperature of $70^{\circ} \mathrm{C}$. The resultant mixture was evaporated under pressure and washed with water to remove the remaining EDC, following which 1.0 equiv Dox (QianKun Chemistry Technology Co., Ltd.) was added and the reaction was set at the temperature of $70^{\circ} \mathrm{C}$ overnight. The product was purified by reverse-phase HPLC with an eluting system consisting of water solution (A) and acetonitrile solution (B) under a linear gradient. The linear gradient stretched over $20 \mathrm{~min}$ from $\mathrm{t}=0 \mathrm{~min}$ at $20 \%$ solution $\mathrm{B}$ to $\mathrm{t}=20 \mathrm{~min}$ at $80 \%$ solution $\mathrm{B}$.

FA-Cis $\left(\mathrm{NH}_{3}, \mathrm{NH}_{3}, \mathrm{Cl}, \mathrm{Cl}\right) \mathrm{Pt}(\mathrm{IV})$-Dox (1). Yellow powders, yield $65 \%$; $\mathrm{Rf}=0.25(\mathrm{PE} / \mathrm{EtOAC}=2: 1)$; ESI-MS calculated for $\mathrm{C}_{64} \mathrm{H}_{82} \mathrm{Cl}_{2} \mathrm{~N}_{12} \mathrm{O}_{25} \mathrm{Pt}(\mathrm{M}+\mathrm{H})^{+}$: 1686.4738; found: 1686.4716 . ${ }^{195} \mathrm{Pt}$ NMR(DMSO-d6): $\delta 1298.21 \mathrm{ppm}$. Calculated for $\mathrm{C}_{64} \mathrm{H}_{82} \mathrm{Cl}_{2} \mathrm{~N}_{12} \mathrm{O}_{25} \mathrm{Pt}$ : C, 45.55; H, 5.02; N, 9.96; O, 23.70. Found: C, 44.35; H, 5.40; N, 9.83; O, 23.02.

$\mathrm{FA}$-Cis $\left(\mathrm{NH}_{3}, \mathrm{NH}_{3}, \mathrm{Cl}, \mathrm{Cl}\right) \mathrm{Pd}(\mathrm{IV})$-Dox (2). Yellow powders, yield 62\%; $\mathrm{Rf}=0.25$ (PE/EtOAC=2:1); ESI-MS calculated for $\mathrm{C}_{64} \mathrm{H}_{82} \mathrm{Cl}_{2} \mathrm{~N}_{12} \mathrm{O}_{25} \mathrm{Pd},(\mathrm{M}+\mathrm{H})^{+}$: 1597.4182; found: 1597.4163 . Calculated for $\mathrm{C}_{64} \mathrm{H}_{82} \mathrm{Cl}_{2} \mathrm{~N}_{12} \mathrm{O}_{25} \mathrm{Pd}$ : C, 48.08; H, 5.30; N, 10.51; O, 25.02; gound: C, 47.86; H, 5.11; N, 10.13, O, 24.92 .

Antiproliferation assay. Target tumor cell lines were grown to log phase in RPMI 1640 medium supplemented with 10\% fetal bovine serum (both Gibco; Thermo Fisher Scientific, Inc.) and $1 \%$ antibiotics. Following diluting to $1 \times 10^{5}$ cells $\mathrm{ml}^{-1}$ with complete medium, $100 \mu \mathrm{l}$ of the obtained cell suspension was added to each well of 96-well culture plates. The cells were incubated with FA-prodrug-Dox at $37^{\circ} \mathrm{C}, 5 \% \mathrm{CO}_{2}$ for $24 \mathrm{~h}$ prior to the cytotoxicity assessments. The samples at pre-set concentrations $(1 \mu \mathrm{g} / \mu \mathrm{l})$ were added to six wells, and Dox and Cis were co-assayed as positive references. After $48 \mathrm{~h}$ exposure at $37^{\circ} \mathrm{C}$ and $5 \% \mathrm{CO}_{2}, 40 \mu \mathrm{l}$ of PBS containing $2.5 \mathrm{mg} \mathrm{ml}^{-1}$ of 3-(4,5-dimethylthiazol-2-yl)-2,5-diphenyltetrazolium bromide was added to each well. After $4 \mathrm{~h}, 100 \mu \mathrm{l}$ per well extraction solution (10\% SDS-5\% isobutyl alcohol-0.01 M HCl) was added. Following incubation overnight at $37^{\circ} \mathrm{C}$, the optical density was measured at $570 \mathrm{~nm}$ on an ELISA microplate reader. In all experiments, three replicate wells were measured for each drug concentration. Each assay was repeated at least three times. The results are summarized in Table I.

Time course of fluorescence emission spectra assay in vitro. In the experiments, incubation was performed in the presence of the reducing agent, GSH. Each FA-prodrug-Dox $(1 \mu \mathrm{M})$ in PBS ( $\mathrm{pH}$ 7.4) was incubated with GSH solution (5 mM), and their fluorescence emissions ( $\lambda \mathrm{ex}=497 ; \lambda \mathrm{em}=594 \mathrm{~nm})$ were measured at different time points. The change in fluorescence emission $(\lambda \mathrm{ex}=497 ; \lambda \mathrm{em}=594 \mathrm{~nm})$ was read using a Cary Eclipse fluorometer (Varian Medical Systems, Inc., Palo Alto, CA, USA).

Fluorescence imaging using confocal laser scanning microscopy. A2780 cells (Chuanbo Biotech Co., Ltd., Nanjing, China) 
Table I. Structure of compounds 1e and 2e, and inhibition of A2780-associated cell line proliferation.

\begin{tabular}{|c|c|c|c|c|c|}
\hline \multirow[b]{2}{*}{ Compound } & \multirow[b]{2}{*}{ M } & \multirow[b]{2}{*}{$\mathrm{X}\left(\mathrm{X}_{1}, \mathrm{X}_{2}\right)$} & \multicolumn{3}{|c|}{$\mathrm{IC}_{50}(\mu \mathrm{M})$} \\
\hline & & & A2780 & A2780/Dox & A2780/Cis \\
\hline 1e & $\mathrm{Pt}$ & $\mathrm{NH}_{3}$ & $0.85 \pm 0.10$ & $8.64 \pm 0.37$ & $0.81 \pm 0.03$ \\
\hline $2 \mathrm{e}$ & $\mathrm{Pd}$ & $\mathrm{NH}_{3}$ & $0.96 \pm 0.08$ & $8.98 \pm 0.68$ & $1.07 \pm 0.11$ \\
\hline Cis & & & $15.60 \pm 1.21$ & $18.10 \pm 1.33$ & $40.80 \pm 0.83$ \\
\hline Dox & & & $1.47 \pm 0.10$ & $20.32 \pm 1.13$ & $1.39 \pm 0.05$ \\
\hline Cis-Dox & & & $12.40 \pm 1.16$ & $16.70 \pm 1.08$ & $41.00 \pm 1.35$ \\
\hline
\end{tabular}

Data are presented as the mean \pm standard deviation. A2780/Dox, Dox-resistant ovarian carcinoma cell lines. A2780/Cis, Cis-resistant ovarian carcinoma cell lines. X, synthesized compound; Dox, doxorubicin; Cis-cisplatin; Pt, platinum; Pd, palladium; $\mathrm{IC}_{50}$, half maximal inhibitory concentration.

at a density of $5 \times 10^{4}$ cells per well were grown in a $35-\mathrm{mm}$ diameter plastic-bottom $\mu$-dish (Ibidi GmbH, Martinsried, Germany) and maintained at $37^{\circ} \mathrm{C}$ in $5 \% \mathrm{CO}_{2}$ for $24 \mathrm{~h}$ prior to treating with FA-Pt (IV)-Dox conjugate $1 \mathrm{e}(1 \mu \mathrm{M})$. At designated time intervals ( 3,6 and $12 \mathrm{~h})$, the medium was removed, and the cells were washed three times with RPMI 1640 medium and twice with PBS. Images of the cells were captured using an LSM 510 confocal laser scanning microscope (Carl Zeiss AG, Oberkochen, Germany) with the appropriate instrument filter sets.

Flow cytometric analysis. The cells were seeded into 24-well plates at a density of $15 \times 10^{4}$ cells per well in $0.5 \mathrm{ml}$ RPMI 1640 medium and incubated in a humidified 5\% $\mathrm{CO}_{2}$ atmosphere for $24 \mathrm{~h}$ at $37^{\circ} \mathrm{C}$. The cells were then treated with FA-Pt (IV)-Dox 1e $(1 \mu \mathrm{M})$ and, at designated time intervals (3, 6 and $12 \mathrm{~h}$ ), the cells were washed three times with RPMI 1640 medium and twice with PBS, following which the cells were harvested by trypsin treatment. The harvested cells were suspended in PBS and centrifuged at $120 \times g$ for $5 \mathrm{~min}$ at room temperature. The supernatants were discarded and the cell pellets were washed with PBS to reduce the background fluorescence from the medium. Following two cycles of washing and centrifugation, the cells were resuspended with $200 \mu \mathrm{l}$ cell fixing solution. One-color flow cytometry was performed using a FACS Calibur flow cytometer (BD Biosciences, Franklin Lakes, NJ, USA). In order to assess the fluorescence enhancement of the compounds upon incubation with A2780 cells, the results were analyzed using FlowJo 7.6.1 software (TreeStar, Inc., Ashland, OR, USA).

Statistical analysis. All biological experiments were repeated 3-5 times with similar outcomes. Where applicable, data are reported as the mean \pm standard deviation.

\section{Results and Discussion}

Chemistry. Six FA-prodrug-Dox derivatives were synthesized. The general reaction pathway for the synthesis is outlined in Fig. 1.

Synthesis of $\mathrm{M}\left(\mathrm{NH}_{3}\right)_{2} \mathrm{Cl}_{2}\left(\mathrm{O}_{2} \mathrm{CCH}_{2} \mathrm{CH}_{2} \mathrm{CO}_{2} \mathrm{H}\right)\left(\mathrm{O}_{2} \mathrm{CCH}_{2}-\mathrm{CH}\right.$ $\left.{ }_{2} \mathrm{CONH}-\mathrm{PEG}-\mathrm{FA}\right)$. Cis-[ $\left.\mathrm{MCl}_{2}\left(\mathrm{NH}_{3}\right)_{2}\right](1 \mathrm{mmol})$ was suspended in water $(5 \mathrm{ml})$, to which a 10 -fold excess of $\mathrm{H}_{2} \mathrm{O}_{2}$ was added. The mixture was stirred for $4 \mathrm{~h}$ at $50^{\circ} \mathrm{C}$. Recrystallization of Cis- $\left[\mathrm{MCl}_{2}(\mathrm{OH})_{2}\left(\mathrm{NH}_{3}\right)_{2}\right]$ was performed in situ, collected and washed with cold water, ethanol and ether, and dried in a desiccator. Succinic anhydride $(4 \mathrm{mmol})$ was added to a suspension of Cis- $\left[\mathrm{MCl}_{2}(\mathrm{OH})_{2}\left(\mathrm{NH}_{3}\right)_{2}\right]$ in DMF $(5 \mathrm{ml})$, and the reaction mixture was stirred at $70^{\circ} \mathrm{C}$ for $4 \mathrm{~h}$. The resulting solution was precipitated by ether and collected. To a solution of Cis- $\left[\mathrm{MCl}_{2}\left(\mathrm{NH}_{3}\right)_{2}\left(\mathrm{O}_{2} \mathrm{CCH}_{2} \mathrm{CH}_{2} \mathrm{CO}_{2} \mathrm{H}\right)_{2}\right]$ in DMF (10 ml), DMF solution $(0.5 \mathrm{ml})$ containing HATU $(1.5 \mathrm{mmol})$ was added. This mixture was stirred for $10 \mathrm{~min}$ at room temperature. To the resulting solution, DMF solution containing PEG linker $(0.8 \mathrm{mmol})$ and DIPEA $(20 \mu \mathrm{l})$ was added. The mixture was stirred at room temperature for $24 \mathrm{~h}$ in the dark. The DMF was then removed under a vacuum and the resulting compound was purified by column chromatography. FA $(0.8 \mathrm{mmol})$ was dissolved in $5 \mathrm{ml}$ DMF coupled with $0.5 \mathrm{mmol}$ of DCC and $1 \mathrm{mmol}$ of NHS. The mixture was stirred for $14 \mathrm{~h}$ at room temperature in the dark to produce folate-NHS ester. The resulting folate-NHS was reacted with $\mathrm{M}\left(\mathrm{NH}_{3}\right)_{2} \mathrm{Cl}_{2}\left(\mathrm{O}_{2} \mathrm{CCH}_{2} \mathrm{CH}_{2} \mathrm{CO}_{2} \mathrm{H}\right)\left(\mathrm{O}_{2} \mathrm{CCH}_{2}-\mathrm{CH}_{2} \mathrm{CONH}-\mathrm{PEG}\right)$ in $\mathrm{DMF}$ and purified by reprecipitation.

Synthesis of $\mathrm{M}\left(\mathrm{NH}_{3}\right)_{2} \mathrm{Cl}_{2}\left(\mathrm{O}_{2} \mathrm{CCH}_{2} \mathrm{CH}_{2} \mathrm{CONH}\right.$-Dox) $\left(\mathrm{O}_{2} \mathrm{CCH}_{2}-\mathrm{CH}_{2} \mathrm{CONH}-\mathrm{PEG}-\mathrm{FA}\right)$. The synthesis of the final Dox-prodrug-FA conjugates was performed using standard amide coupling reactions. Following the procedure mentioned above, 1.0 equiv prodrug-PEG-FA $(0.5 \mathrm{mmol})$ was reacted with 1.5 equiv EDC coupled with DIPEA $(20 \mu \mathrm{l})$ in $2 \mathrm{ml}$ $\mathrm{DMF}$ at the temperature of $70^{\circ} \mathrm{C}$, the resulting mixture was evaporated under pressure and washed with water to remove the remaining EDC. Subsequently, 1.0 equiv Dox was added and incubated at a temperature of $70^{\circ} \mathrm{C}$ overnight. The general formula of the final purified compound was Dox-[Pt (IV)/Pd (IV)]-FA.

Synthesis of $\mathrm{Pt}\left(\mathrm{NH}_{3}\right)_{2} \mathrm{Cl}_{2}\left(\mathrm{O}_{2} \mathrm{CCH}_{2} \mathrm{CH}_{2} \mathrm{CONH}\right.$-Dox) $\left(\mathrm{O}_{2} \mathrm{CCH}_{2} \mathrm{CH}_{2} \mathrm{CO}_{2} \mathrm{H}\right.$; Cis-Dox). To a solution of Cis- $\left[\mathrm{PtCl}_{2}\right.$ $\left.\left(\mathrm{NH}_{3}\right)_{2}\left(\mathrm{O}_{2} \mathrm{CCH}_{2} \mathrm{CH}_{2} \mathrm{CO}_{2} \mathrm{H}\right)_{2}\right](10 \mathrm{mg})$ in DMF (5 ml), 1.5 equiv EDC coupled with DIPEA $(10 \mu \mathrm{l})$ was added at the temperature of $70^{\circ} \mathrm{C}$ for $6 \mathrm{~h}$. The solution was removed and washed with water to remove the remaining EDC, following which 1.0 equiv Dox was added and incubated at a temperature of $70^{\circ} \mathrm{C}$ overnight. The obtained compound was used as a control 
Scheme 1

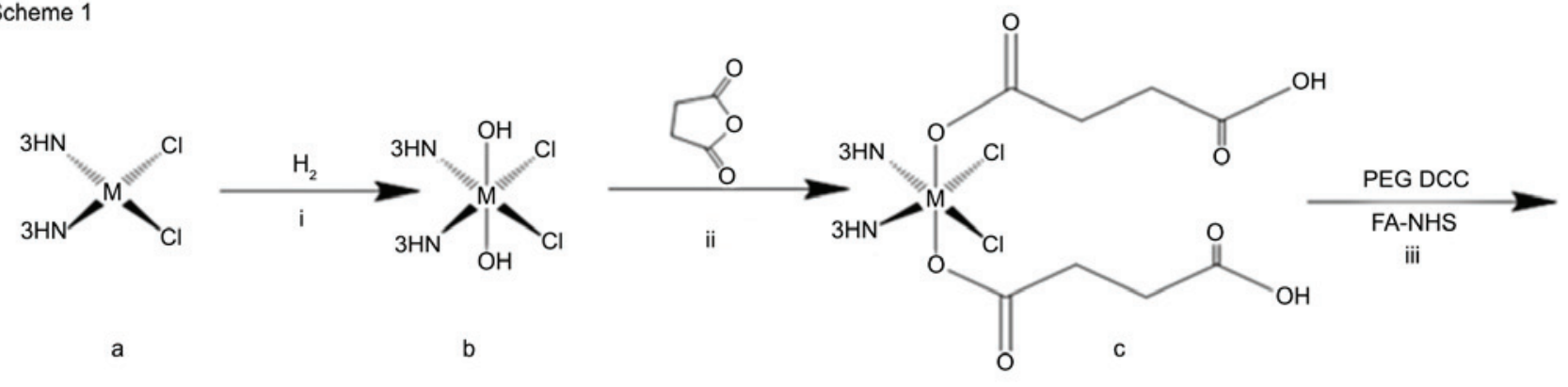

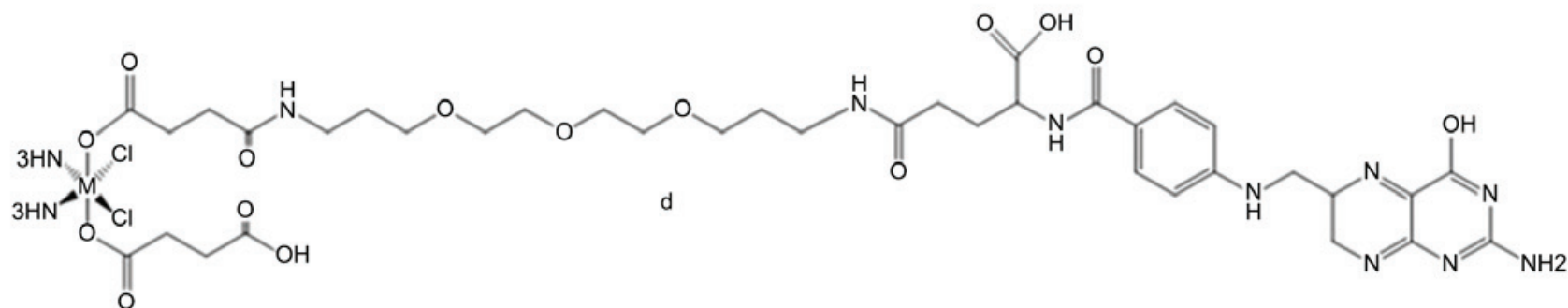

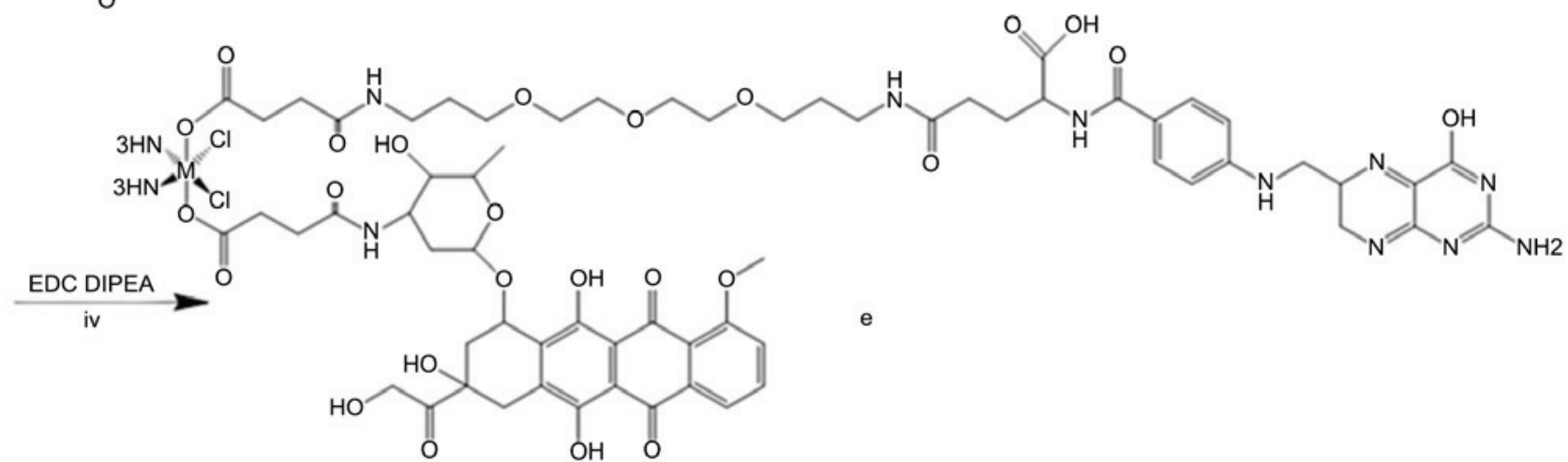

Figure 1. General synthesis of compounds 1e, and 2e. Reagents and conditions were as follows: (i) $\mathrm{H}_{2} \mathrm{O}_{2}, 50^{\circ} \mathrm{C}, 4 \mathrm{~h}$; (ii) succinic anhydride, $70^{\circ} \mathrm{C}, 4 \mathrm{~h}$; (iii) PEG, DCC, room temperature, Folate-NHS, 24 h. (iv) EDC, DIPEA, $70^{\circ} \mathrm{C}$, overnight. Dcc, dicyclohexylcarbodiimide; NHS, N-hydroxysuccinimide; EDC, 1-ethyl-3-(3-dimethylaminopropyl) carbodiimide; PEG, polyethylene glycol; DIPEA, N,N-diisopropylethylamine.

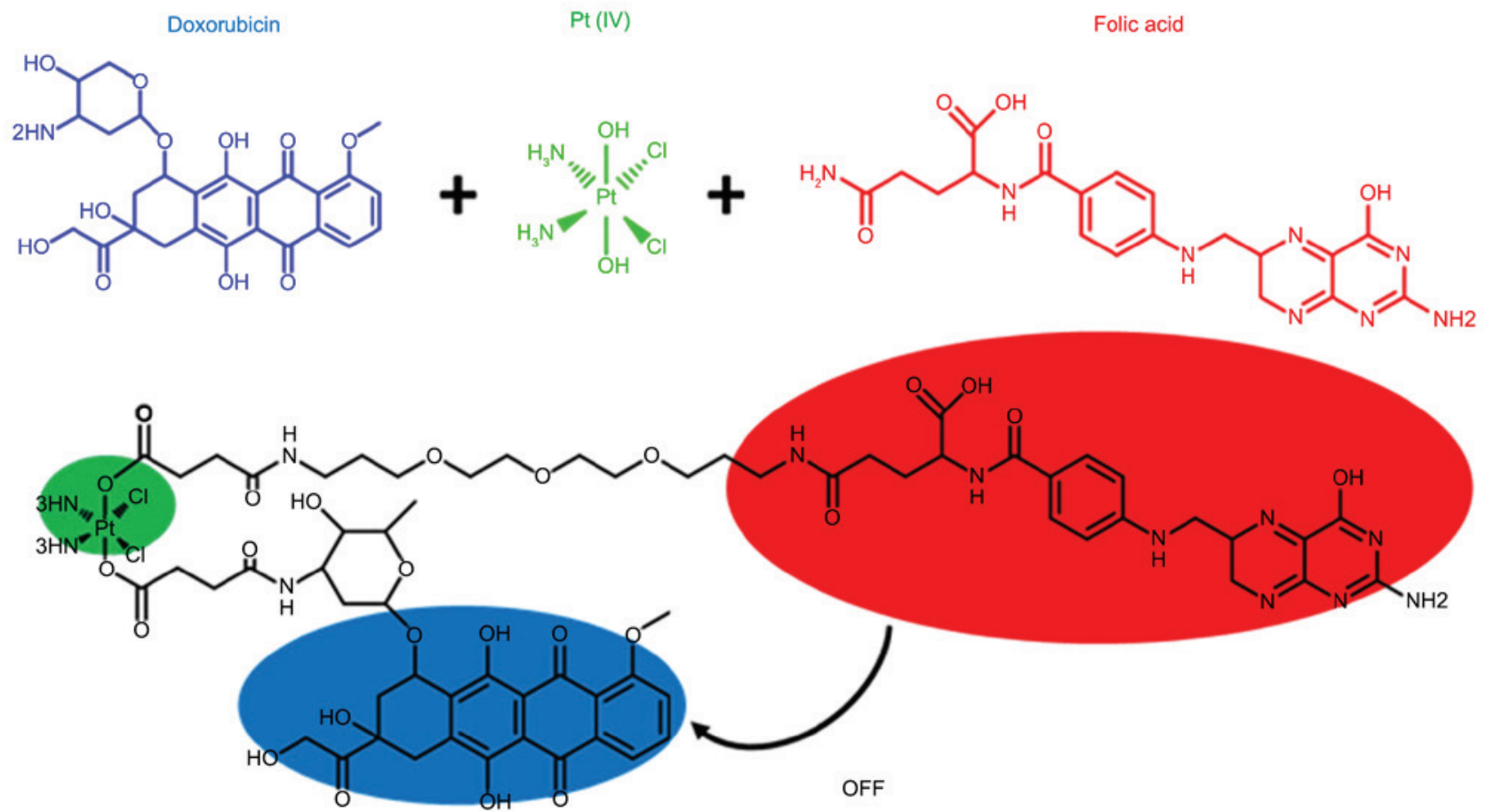

Figure 2. Structures of Folic acid-Pt (IV)-Dox used as novel template for combination chemotherapy with real-time imaging. Dox, doxorubicin; Pt, platinum. 


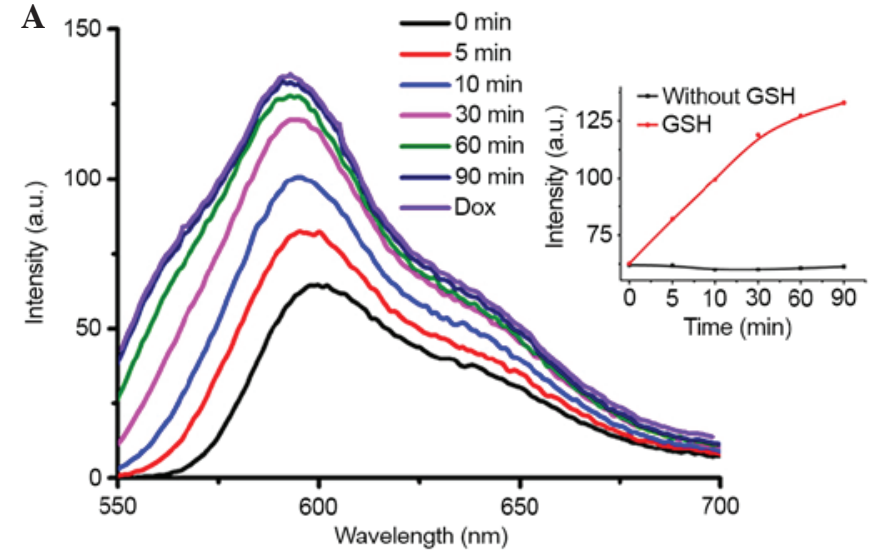

B

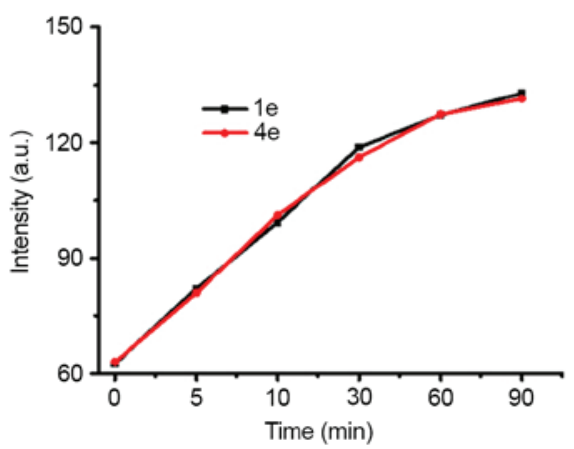

Figure 3. Fluorescence emission. (A) Time course of fluorescence emission spectra assay showing activation of the fluorescent FA-prodrug-Dox by GSH $(5 \mathrm{mM})$. Enhanced fluorescence emission $(\lambda$ ex $=497 ; \lambda$ em $=594 \mathrm{~nm})$ was observed following treatment with FA-prodrug-Dox $1(10 \mathrm{nM})$ in PBS $(\mathrm{pH} 7.4)$ with $\mathrm{GSH}$ at $37^{\circ} \mathrm{C}$. The inset shows that the fluorescence of $1 \mathrm{e}$ $(10 \mathrm{nM})$ in PBS (pH 7.4) was not altered in the absence of GSH, leaving the compound in its initial quenched state. (B) Comparison between the fluorescence of 1e and 2e under the same conditions in the presence of GSH. FA, folic acid; Dox, doxorubicin; GSH, glutathione.

to further confirm the FA-targeting effect of the designed compounds (Fig. 2).

Biological activity. To assess the anticancer activities of the synthesized compounds, the present study evaluated the antiproliferative activities against A2780, A2780/Dox and A2780/ Cis cell lines. As shown in Table I, all the compounds showed marked activity against ovarian cancer cells, suggesting that the FA-prodrug-Dox derivatives exhibited improved efficacy, compared with the single drugs of Dox and Cis. In addition, the target compounds exhibited a more potent effect, compared with the additive effect of the two cytotoxins (Dox-Cis), the superiority of the designed compounds were predominantly attributed to the function of FA-targeting. For the compounds, it was observed that compound 1e showed the most potent biological activity, with half maximal inhibitory concentration $\left(\mathrm{IC}_{50}\right)$ values of $0.85 \pm 0.10,8.64 \pm 0.37$ and $0.81 \pm 0.03 \mu \mathrm{M}$ against the A2780, A2780/Dox and A2780/Cis cell lines, respectively.

In addition, the activity of the assessed compounds was correlated with the core metallic atom variation and ligand modifications (Fig. 3). It was revealed that Pd had a similar antiproliferative activity to $\mathrm{Pt}$, suggesting that $\mathrm{Pd}$ derivatives qualified as a novel substitute for Pt as an anticancer drug.
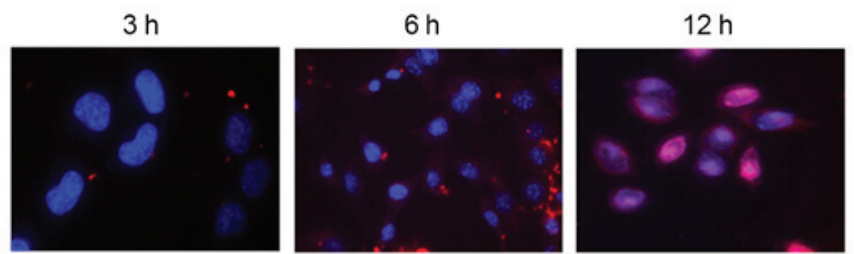

Figure 4. Live-cell fluorescent imaging of A2780 cells treated with 1e. Fluorescence microscopy images showed enhanced fluorescence within $12 \mathrm{~h}$ due to the intercalation of $1 \mathrm{e}(1 \mu \mathrm{M}$ in PBS; pH 7.4) with the nucleus of the folate receptor-expressing A2780 cell line. Nuclei were stained with DAPI (blue).

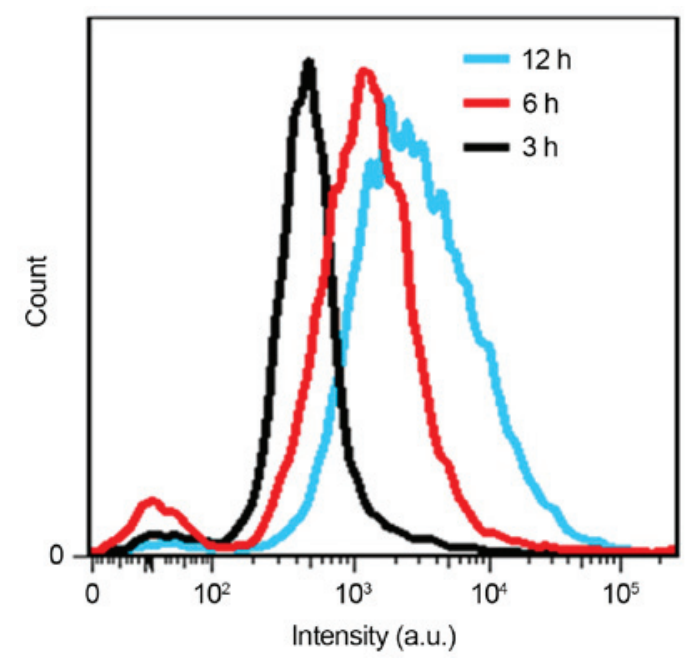

Figure 5. In vitro flow cytometric analysis of the activation of the fluorescent prodrug. Enhanced fluorescence emission was due to activation of the prodrug and the resulting fluorescence turn-on of doxorubicin in the A2780 cell line (10,000 cells).

In line with the improved anticancer potency, the present study further investigated the process of drug release in cancer cells with fluorescent imaging. The fluorescence activation was first assessed by treating cells with the FA-prodrug-Dox in reducing conditions and in the presence of GSH. In these experiments, compound $1 \mathrm{e}(1 \mu \mathrm{M})$ in PBS ( $\mathrm{pH}$ 7.4) was incubated with GSH solution (5 mM), as the intracellular GSH concentration is between 1 and $10 \mathrm{mM}$. The fluorescence emissions $(\lambda \mathrm{ex}=497 ; \lambda \mathrm{em}=594 \mathrm{~nm})$ were measured at different time points. As shown in Fig. 4A, the fluorescence emission of FA-Pt (IV)-Dox increased 2-fold as a result of reduction of the axial bond, reaching a plateau at $1 \mathrm{~h}$. In addition, treatment with FA-Pt (IV)-Dox $(1 \mu \mathrm{M}$ in PBS; pH 7.4) in the absence of GSH (PBS pH 7.4) showed no effect on the fluorescence emission of Dox, suggesting that the observed increase in the fluorescence of Dox was due to GSH-mediated cleavage of the axial bond of the prodrug. The present study further investigated the drug release of FA-Pd (IV)-Dox (2e), which showed a similar trend of fluorescent enhancement with FA-Pt (IV)-Dox (1e), as shown in Fig. 4B, indicating there was no significant difference in the release efficiency between the Pt (IV) and Pd (IV) complexes (Fig. 5).

In conclusion, a series of FA-prodrug-Dox derivatives were synthesized in the present study and were evaluated 
for multifunctional anticancer therapy. These compounds exhibited potent antitumor activities against ovarian cell lines. Among them, compound le demonstrated the most potent activity, with $\mathrm{IC}_{50}$ values of $0.85 \pm 0.10,8.64 \pm 0.37$ and $0.81 \pm 0.03 \mu \mathrm{M}$ against A2780, A2780/Dox and A2780/Cis cell lines, respectively. The fluorescence imaging of live cell lines also provided an easy and reliable method for monitoring of the site-specific drug activities through turn-on systems induced by drug release. The results of the present study may provide assistance in the treatment of ovarian cancer cells with improved efficiency and real-time imaging, which can be used as a multifunctional system for the optimization of anticancer drugs.

\section{References}

1. Mareel M and Leroy A: Clinical, cellular, and molecular aspects of cancer invasion. Physiol Rev 83: 337-376, 2003.

2. Weigelt B, Peterse JL and Van't Veer LJ: Breast cancer metastasis: Markers and models. Nat Rev Cancer 5: 591-602, 2005.

3. Oldenburg RA, Meijers-Heijboer H, Cornelisse CJ and Devilee P: Genetic susceptibility for breast cancer: How many more genes to be found? Crit Rev Oncol Hematol 63: 125-149, 2007.

4. Nowsheen S, Aziz K, Tran PT, Gorgoulis VG, Yang ES and Georgakilas AG: Epigenetic inactivation of DNA repair in breast cancer. Cancer Lett 342: 213-222, 2014.

5. Leber MF and Efferth T: Molecular principles of cancer invasion and metastasis (review). Int $\mathbf{J}$ Oncol 34: 881-895, 2009.

6. Yoo HS and Park TG: Biodegradable polymeric micelles composed of doxorubicin conjugated PLGA-PEG block copolymer. J Control Release 70: 63-70, 2001.

7. Low PS and Antony AC: Folate receptor-targeted drugs for cancer and inflammatory diseases. Adv Drug Deliv Rev 56: $1055-1058,2004$.
8. Lu Y, Sega E, Leamon CP and Low PS: Folate receptor-targeted immunotherapy of cancer: Mechanism and therapeutic potential. Adv Drug Deliv Rev 56: 1161-1176, 2004.

9. Hilgenbrink AR and Low PS: Folate receptor-mediated drug targeting: From therapeutics to diagnostics. J Pharm Sci 94 2135-2146, 2005.

10. Santra S, Kaittanis C, Santiesteban OJ and Perez JM: Cell-specific, activatable, and theranostic prodrug for dual-targeted cancer imaging and therapy. J Am Chem Soc 133: 16680-16688, 2011.

11. Sledge GW, Neuberg D, Bernardo P, Ingle JN, Martino S, Rowinsky EK and Wood WC: Phase III trial of doxorubicin, paclitaxel, and the combination of doxorubicin and paclitaxel as front-line chemotherapy for metastatic breast cancer: An intergroup trial (E1193). J Clin Oncol 21: 588-592, 2003.

12. Heister E, Neves V, Silva SRP, Mcfadden J and Coley HM): Carbon nanotubes loaded with anticancer drugs: A platform for multimodal cancer treatment. In: Carbon Nanotubes for Biomedical Applications. Klingeler R and Sim RB (eds). Springer-Verlag GmbH, Berlin, pp223-245, 2009.

13. Karukstis KK, Thompson EH, Whiles JA and Rosenfeld RJ: Deciphering the fluorescence signature of daunomycin and doxorubicin. Biophys Chem 73: 249-263, 1998.

14. Jakupec MA, Galanski M and Keppler BK: Tumor-inhibiting platinum complexes-state of the art and future perspectives. Rev Physiol Biochem Pharmacol 146: 1-54, 2003.

15. Hall MD, Mellor HR, Callaghan R and Hambley TW: Basis for design and development of platinum (IV) anticancer complex. J Med Chem 50: 3403-3411, 2007.

16. Tyagi AK, Agarwal C, Chan DC and Agarwal R: Synergistic anti-cancer effects of silibinin with conventional cytotoxic agents doxorubicin, cisplatin and carboplatin against human breast carcinoma MCF-7 and MDA-MB468 cells. Oncol Rep 11: 493-499, 2014.

17. Chun R, Kurzman ID, Couto CG, Klausner J, Henry C and MacEwen EG: Cisplatin and doxorubicin combination chemotherapy for the treatment of canine osteosarcoma: A pilot study. J Vet Intern Med 14: 495-498, 2000.

18. Harrington KJ, Syrigos KN, Uster PS, Zetter A, Lewanski CR, Gullick WJ, Vile RG and Stewart JS: Targeted radiosensitisation by pegylated liposome-encapsulated 3', 5'-O-dipalmitoyl 5-iodo-2'-deoxyuridine in a head and neck cancer xenograft model. Br J Cancer 91: 366-373, 2004. 